\title{
Influence of Cobalt Supplementation on Feed Intake Nutrient Digestibility and Body Weight Change in Goats Fed Corncob-Based Diet
}

\author{
Olajide Peter 0
}

Department of Crop and Soil Science, College of Agricultural Sciences, Landmark University, Omu-Aran, Nigeria

Corresponding author: Olajide Peter O, Department of Crop and Soil Science, College of Agricultural Sciences, Landmark University, Omu-Aran, Nigeria, Tel: +2347061507673; E-mail: olajidepeter77@yahoo.com

Received Date: November 30, 2016; Accepted Date: January 04, 2017; Published Date: January 11, 2017

Copyright: (C) 2017 Olajide PO. This is an open-access article distributed under the terms of the Creative Commons Attribution License, which permits unrestricted use, distribution, and reproduction in any medium, provided the original author and source are credited.

Citation: Olajide PO. Influence of Cobalt Supplementation on Feed Intake Nutrient Digestibility and Body Weight Change in Goats Fed Corncob Based Diet. J Anim Sci Livest Prod. 2016, 1:1.

\section{Abstract}

A 12-week feeding trial was conducted to study the response of West African Male Dwarf goats to a corncobbased diet supplemented with varied levels $(0.00,0.50,0.75$ $\mathrm{mg} / \mathrm{kg} \mathrm{DM}$ ) of cobalt chloride. Twelve West African Dwarf goats of similar body weights $(8.48 \pm 1.24 \mathrm{~kg})$ were allotted to three dietary groups, each of four replicates in a randomized complete block design experiment. The goats were kept on corncob-based concentrate diet (ad libitum) with unrestricted access to clean drinking water throughout the period of the feeding trial. The study examined the effects of treatments on feed intake, dry matter and nutrients digestibility, feed conversion efficiency and body weight gain in the goats.

Results from the study showed that the corncob-based concentrate diet was acceptable to the goats and resulted in moderate $(p>0.05)$ body weight gain $(20.24,19.40$ and $20.09 \mathrm{~g} /$ head day for goats fed $0.00,0.50$ and $0.75 \mathrm{mg}$ cobalt chloride/kg DM respectively). Crude fiber digestibility $(\%)$ increased $(p<0.05)$ from 63.27 in the control group to 70.47 in goats fed cobalt chloride supplement at $0.75 \mathrm{mg} / \mathrm{kg}$ DM. Feed conversion ratio was slightly ( $p>0.05)$ improved in goats that received the $0.75 \mathrm{mg}$ cobalt/ $\mathrm{kg}$ DM treatment (11.53) over the control group (12.14). No significant difference $(p>0.05)$ was observed between dietary groups for parameters evaluated other the crude fiber digestibility. It was concluded that cobalt chloride dietary supplement at $0.75 \mathrm{mg} / \mathrm{kg}$ DM level enhanced digestibility of crude fiber in corncob-based concentrate diet for West African Dwarf goats.

Keywords: Cobalt; Corncob; Goat; Feed; Nutrient; Digestibility; Body weight

\section{Abbreviations}

DM: Dry Matter; CP: Crude Protein; CF: Crude Fibre; EE: Ether Extract; ADF: Acid Detergent Fibre; NDF: Neutral Detergent Fibre; ADL: Acid Detergent Lignin.

\section{Introduction}

Sustainability of feeds supply to livestock is a great challenge in Sub-Saharan Africa. The challenge has made the need to source for unconventional feeds and feedstuffs as alternatives, a priority in the livestock industry. Alternative feeds can satisfactorily complement the conventional feed resources if the appropriate processing and supplementation approaches are adopted. Among such unconventional feed resources is corncoban abundant by-product of maize crop production that is seldom utilized for feeding purpose, in spite of its potentials in ruminant diets formulation. Corncob contains a considerable reservoir of fibrous complex-carbohydrates, mainly cellulose, hemicelluloses and lignin [1].

Strategies appropriate for enhancing the utilization of high fiber diets in ruminants include the use of exogenous fibrolytic enzyme [2], chemical and mechanical processing [3], and supplementation for enhanced rumen microbial activities [4]. Certain trace mineral elements including zinc, copper, nickel and cobalt have been identified [5] to influence cellulose digestion in the rumen. Lopez-Guisa and Satter [6] reported that cobalt supplementation above that required for B12 synthesis could improve the utilization of poor quality forages. Cobalt concentrations in plant based foods are very low [7].

The hypothesis tested in the present study is that dietary cobalt supplementation can improve growth performance of goats on low quality plant based concentrate diets. The study examined the effects of varied levels of cobalt chloride supplements on dry matter intake, nutrient digestibility and body weight change in West African Dwarf goats fed a concentrate diet composed largely of plant feedstuffs. Cobalt is an essential trace element for ruminants which can synthesize vitamin B12 in the digestive tract by microbial action [8].

\section{Statement of the Problem}

Corncob like several other fibrous crop residues, have poor feeding values for minerals. The corncob is characterized by low nutrient density and digestibility. Available options for improvement of the feeding value of corncob in ruminant feed are; pre-digestion with exogenous enzymes, alkali treatment and 
nutrient supplementation. The latter option is more tenable for adoption by the rural farmer.

\section{Importance of the Study}

The use of corncob in livestock feeds production affords an opportunity to convert a major crop by-product and a potential source of pollution in the environment into valuable animal products. Small ruminants seem to be more efficient in the utilization of coarse feedstuff for the production of meat, preferring feedstuffs relatively rich in crude fiber (Williamson and Payne, 1987). Corncob and Gliricidia sepium is abundant in almost every part of Nigeria.

\section{Cobalt Chloride}

Cobalt is essential in goat diets for the synthesis of vitamin B12. Cobalt may also be beneficial in goat diets as a means of improving the efficiency of fiber digestion by bacteria. Although cobalt requirements are less than $1 \mathrm{ppm}$ in the diet, cobalt deficiency has devastating effects on animal health.

\section{Materials and Methods}

\section{Site and duration of the feeding trial}

Growth performance characteristics of goats fed cobalt chloride supplements in a corncob based concentrate diet were assessed under a sub-humid tropic environment (Latitude, 08: $29^{\circ} \mathrm{N}$; Longitude, 04: $35^{\circ} \mathrm{E}$ ) during the dry season months of February-May.

\section{Feedstuffs and formulation of diets}

Corncobs and Gliricidia sepium tree leaves were separately dried under well-ventilated room conditions, milled to pass through a 2-mm sieve and preserved in jute bags for subsequent feed formulation. A concentrate diet made up of corncob $(50 \%)$, gliricidia leaf meal (27\%), maize bran (20\%), urea (1\%), bone meal $(1 \%)$, and salt (1\%) was prepared.

\section{Animals and treatments}

Twelve (12) West African Male Dwarf (WAMD) goats with average body weight of $8.48 \pm 1.24 \mathrm{~kg}$ initially, were used for the study. The animals were dewormed and treated against ectoparasites [10] as part of routine management practices. Goats were randomly assigned to three dietary groups each made up of four replicates. Treatments consisted of dietary levels of cobalt as cobalt chloride at $0.00,0.50,0.75 \mathrm{mg} / \mathrm{kg}$ diet DM. The experiment lasted for 12 weeks. The goats were transferred in the last two weeks to individual metabolism cages that allowed for separate collection of feces and urine, following a 7-day period of adjustment to the cage conditions. Goats were weighed fortnightly before early morning feeding and had unrestricted access to drinking water throughout the 84-day period.

\section{Collection of samples and analyses}

Feed samples were analyzed for proximate composition. Feeds, orts and fecal samples were collected from individual goat daily at 08.00 hour prior to feeding during the last seven days and oven dried at $60^{\circ} \mathrm{C}$. About $10 \%$ of the samples were composited for each animal and analyzed for dry matter, ether extract, crude protein, neutral detergent fiber and acid detergent fiber [10]. Urine samples were collected into plastic buckets previously acidified with $20 \mathrm{ml} \mathrm{H}_{2} \mathrm{SO}_{4}(10 \% \mathrm{v} / \mathrm{v})$. About $10-\mathrm{ml}$ sub-samples of daily urine productions were separately composited for each goat and analyzed for total nitrogen by the Khejdal method [11].

\section{Data analysis}

The data obtained were analyzed using the procedure of statistical system (SAS) [12]. The statistical model used in the analysis of the growth trial was:

Where,

$$
\begin{aligned}
& \text { Yijk= Dependent variable } \\
& \mu=\text { Overall mean } \\
& \mathrm{Ti}=\text { Effect of the treatment } \\
& \text { eijk= Random error, independent and normally distributed }
\end{aligned}
$$

\section{Results and Discussion}

\section{Results}

The composition of the corncob-based concentrate diet was as shown in (Table 1). Maize offal provided fermentable carbohydrates while urea furnished fermentable nitrogen, that are both required for metabolism by the rumen microorganisms. The use of Gliricidia sepium leaf meal at $27 \%$ inclusion level was meant to reduce the cost of feed formulation, provide additional fermentable organic matter to the rumen microbes and adoption of the study by the resource poor livestock farmer. The corncob-based diet, with crude protein and energy levels of $12.54 \% \mathrm{DM}$ and $23.97 \mathrm{Mcal} / \mathrm{kg}$ DM respectively was considered adequate for productive performance in goats kept under intensive management [13]

Table 1 Composition of Diet.

\begin{tabular}{|l|l|}
\hline Ingredient & Percentage (\%) \\
\hline Ground Corncob & 50 \\
\hline Gliricidia leaf meal & 27 \\
\hline Maize offal & 20 \\
\hline Urea & 1 \\
\hline Bone meal & 1 \\
\hline Salt & 1 \\
\hline DM and proximate & Percentage (\%) \\
\hline DM & 88.85 \\
\hline
\end{tabular}




\begin{tabular}{|l|l|}
\hline CP & 12.46 \\
\hline CF & 18.48 \\
\hline EE & 6.01 \\
\hline Ash & 10.94 \\
\hline ADF & 15.83 \\
\hline NDF & 23.25 \\
\hline ADL & 5.63 \\
\hline Calculated energy & $23.97 \mathrm{Mcal} / \mathrm{kg}$ \\
\hline
\end{tabular}

No sign of impaired health that could be attributed to diet or treatment effect was observed in the goats throughout the 84day feeding trial. Dry matter intake among the three dietary groups were similar $(p>0.05)$ and averaged 238.07 g/day. Dry matter intake expressed in terms of metabolic body weight (g/BW ${ }^{0.75} \mathrm{Kg}$ ) were 23.67 and 22.91 for goats fed cobalt chloride at 0.05 and $0.75 \mathrm{mg} / \mathrm{kg} \mathrm{DM}$ respectively and 24.02 for the control group indicating a slight reduction ( $p>0.05)$ caused by cobalt supplement (Table 2).

Table 2 Nutrient Intake and Digestibility in WAMD Goats fed Corncob Diet supplemented with cobalt chloride.

\begin{tabular}{|c|c|c|c|c|}
\hline $\begin{array}{l}\text { Item/CoCl2 } \\
\text { inclusion level }\end{array}$ & 0 & 0.5 & 0.75 & \pm SEM \\
\hline \multicolumn{5}{|l|}{ Dry Matter } \\
\hline Intake, g/BW 0.75 Kg & 24.02 & 23.67 & 22.91 & 4.66 \\
\hline Digestibility, \% & 71.29 & 68.15 & 72.74 & 10.45 \\
\hline \multicolumn{5}{|l|}{ Crude Protein } \\
\hline Intake, g/BW ${ }^{0.75} \mathbf{K g}$ & 3.39 & 3.32 & 3.21 & 1.18 \\
\hline Digestibility, \% & 49.10 & 49.05 & 46.15 & 7.13 \\
\hline \multicolumn{5}{|l|}{ Crude Fiber } \\
\hline Intake, g/BW ${ }^{0.75} \mathrm{Kg}$ & 5.03 & 4.92 & 4.75 & 2.5 \\
\hline Digestibility, \% & $63.27^{\mathrm{b}}$ & $65.27^{\mathrm{b}}$ & $70.47^{a}$ & 8.13 \\
\hline \multicolumn{5}{|l|}{ Ether Extract4 } \\
\hline Intake, g/BW ${ }^{0.75} \mathbf{K g}$ & 1.64 & 1.60 & 1.55 & 0.76 \\
\hline Digestibility, \% & 52.8 & 49.39 & 51.81 & 11.14 \\
\hline \multicolumn{5}{|c|}{ Neutral Detergent Fiber, NDF } \\
\hline Intake, $\mathbf{g} / \mathbf{B W}^{0.75} \mathbf{K g}$ & 6.33 & 6.20 & 5.99 & 2.28 \\
\hline Digestibility, \% & 43.50 & 41.76 & 42.72 & 3.07 \\
\hline \multicolumn{5}{|c|}{ Acid Detergent Fiber, ADF } \\
\hline Intake, $\mathbf{g} / \mathbf{B W}^{0.75} \mathbf{K g}$ & 4.31 & 4.22 & 4.08 & 1.67 \\
\hline Digestibility, \% & 45.90 & 44.35 & 46.25 & 5.38 \\
\hline
\end{tabular}

a, b-Mean within a row with different superscript letter differ $(p<0.05)$.

The average dry matter consumption $\left(\mathrm{g} / \mathrm{BW}^{0.75} \mathrm{Kg}\right.$ ) by goats in the present study was within the range of values (48.24-52.88) reported by Ogungbesan et al. [14] for West African Dwarf goats fed Tephrosia bracteolata (Gull Et Perr) based diets. The effects of cobalt chloride supplements on the digestibility of dry matter and nutrients except for crude fibre were not significant $(p>0.05)$. Similar observation on the digestibility of DM, NDF and ADF had been reported [15] in Sahiwal cows fed a basal diet of Para grass plus concentrate mixture supplemented with trace mineral capsule containing $\mathrm{Cu}$, Co, M and Zn. Nagabhushana et al., [16] noted that cobalt supplementation over and above inherently available in the diet had no effect on the efficiency of nutrient utilization or intake in growing calves.

The growth performance characteristics of WAMD goats, in response to cobalt supplementation on corncob based diet were as indicated in Table 3.

Table 3 Influence of cobalt supplement on feed intake, body weight gain of WAMD goats.

\begin{tabular}{|l|l|l|l|l|}
\hline Item/Treatment & $\mathbf{0}$ & $\mathbf{0 . 5}$ & $\mathbf{0 . 7 5}$ & $\mathbf{\pm}$ SEM \\
\hline Duration, day & 84 & 84 & 84 & - \\
\hline Initial body weight, kg & 8.51 & 8.42 & 8.50 & 1.09 \\
\hline Final body weight, kg & 10.21 & 10.05 & 10.19 & 3.41 \\
\hline $\begin{array}{l}\text { Body weight change, } \\
\text { kg }\end{array}$ & 1.70 & 1.63 & 1.68 & 1.12 \\
\hline $\begin{array}{l}\text { Average body weight } \\
\text { change, g/day }\end{array}$ & 20.24 & 19.40 & 20.09 & 4.17 \\
\hline $\begin{array}{l}\text { Daily feed intake, g DM/ } \\
\text { head/day }\end{array}$ & 245.75 & 236.65 & 231.80 & 10.01 \\
\hline $\begin{array}{l}\text { Feed Conversion Ratio, } \\
\text { feed/gain }\end{array}$ & 12.14 & 12.19 & 11.53 & 1.60 \\
\hline $\begin{array}{l}\text { SEM-standard error of the treatment means } \\
\text { a, b-Mean within a row with different superscript letter differ (p<0.05). }\end{array}$ \\
\hline
\end{tabular}

Supplementation of the corncob-based diet with cobalt caused a slight depression $(p<0.05)$ in feed intake and body weight gain in the goats. The average live weight gain (g/day) decreased slightly $(p>0.05)$ from 20.24 in the control group to 20.09 and 19.40 in goats that 0.75 and $0.50 \mathrm{mg}$ cobalt chloride treatments respectively probably due to a corresponding decrease in dry matter intake since the rates of dry matter digestion were similar $(p>0.05)$ in the three dietary groups. Depression in body weight gain was observed by Lopez-Guisa and Satter [6] in heifers fed low quality forage supplemented with $\mathrm{Co}$ and $\mathrm{Cu}$ in excess of NRC recommendations.

\section{Discussion}

The observed depressed feed intake and decreased weight gain in this study is probably due to a corresponding decrease in dry matter intake since the rates of dry matter digestion were similar $(p>0.05)$ in the three dietary groups. Depression in body 
weight gain was observed by Lopez-Guisa and Satter [6] in heifers fed low quality forage supplemented with $\mathrm{Co}$ and $\mathrm{Cu}$ in excess of NRC recommendation.

The result in DM digestibility is in line with Tiffany [17] report that apparent DM digestibility of the control diet, without Co addition, did not differ from diets supplemented with Co. However, mixed ruminal cultures supplemented with $0.10 \mathrm{mg}$ $\mathrm{Co} / \mathrm{kg}$ had lower apparent digestibility than cultures fed diets supplemented with either 0.05 or $1.0 \mathrm{mg} \mathrm{Co} / \mathrm{kg}$ DM. Smith and Marston reported that if Vitamin B12 is not in good supply [18], Cobalt may not have effect on DM digestibility, so it may be assumed in this study that the goats were not deficient iv Vitamin B12. Corn cob is generally considered as roughage that contains high fiber and is hardy in nature. As a result, feed intake is reduced and retention time of roughage in the rumen is increased, however, supplementation of the diet with gliricidia leaf meal may have increased the availability of nutrients to rumen microbes by rectifying energy and nitrogen imbalances in the rumen and stimulating the rumen microbial activity [3]. Reynolds and Cobbina [19] also stated that when roughage was supplemented with concentrates, it enhanced the feed digestibility and intake of animals. Nevertheless, Devendra [20], Stewart and Simons [21] and Nguyen and Nguyen [22] confirmed that when used as a supplement, the optimum level of fresh fodder trees and shrubs should be about $30-50 \%$ of the ration on dry matter basis. The fodder was included at a lower level in this study and assumed to have been well utilized.

Using urea as an agent to improve the nutritional value of low quality by products is still considered as the most favorable up till now. Ojai et al., [23] stated that feed grade urea or the equivalent weight of fertilizer grade urea can be used to improve the nutritional value of chopped cobs (approximately $1 \mathrm{~cm}$ length) in terms of N, DM, NDF, ADF and OM for small ruminant feeding during off season periods.

\section{Conclusion}

The suitability of the concentrate diet constituted manly from corncob and Gliricidia sepium leaf meal was West African dwarf goats has been demonstrated by the study. The diet which was moderately consumed and digested but had no apparent adverse effect on the health of the animals can be suggested for dry season feeding of goats. The rate of intake by the goat was sufficient to produce positive weight balance over the 12-week. Supplementation of the corncob-based diet with 0.5 or $0.75 \mathrm{mg}$ cobalt-chloride/kg DM had no influence on dry matter or nutrient intake and body weight change. The $0.75 \mathrm{mg}$ cobaltchloride/kg DM level of supplementation improved crude fiber digestibility. Subsequent studies would be on the effect of cobalt chloride supplementation above the $0.75 \mathrm{mg} / \mathrm{kg} \mathrm{DM}$ level, the use of other chemical compounds of cobalt as supplements and the digestion kinetics in the rumen to further improve the utilization of the corncob-based diet in small ruminants.

\section{Acknowledgement}

The study received financial support from the Tertiary Education Trust Fund, TETFUND, through the Research,
Technology and Innovation Unit, University of Ilorin, Ilorin, Nigeria.

\section{References}

1. Donelly BJ (1973) the carbohydrate composition of corncob Hemicelluloses. American Association of Cereal Chemist.

2. Beauchemin KA, Colombatto D, Morgavi DP, Yang WZ (2003) Use of Exogenous Fibrolytic Enzymes to Improve Feed Utilization by Ruminants. J Anim Sci 81: E37-E47.

3. Ibrahim MNM, Pearce GR (1983) A soak-and-press method for the alkali treatment of fibrous crop residues. Laboratory studies on aspects of the procedure. Agric Wastes 8: 195-213.

4. Migwi PK, Bebe BO, Gachuiri CK, Godwin I, Nolan JV (2013) Options for efficient utilisation of high fibre feed resources in low input ruminant production systems in a changing climate: A review. Livest Res Rural Develop 25.

5. Martinez A, Church DC (1970) Effect of Various Mineral Elements on In Vitro Rumen Cellulose Digestion. J Anim Sci 31: 982-990.

6. Lopez-Guisa JM, Satter ID (1992) Effect of copper and cobalt addition on digestion and growth in heifers fed diets containing alfalfa silage on corn crop residues. J Dairy Sci 75: 247-256.

7. EFSA, European Food Safety Authority (2009) Scientific Opinion on the use of cobalt compounds as additives in animal nutrition-EFSA Panel on Additives and Products or Substances used in Animal Feed. EFSA J 7: 1383.

8. NRC, National Research Council (1989) In: Nutrient Requirements of Dairy Cattle, (7th edn.) Nutrient requirement of domestic animals, National Academy of Sciences, Washington DC, New York.

9. Olafadehan OA (2011) Changes in haematological and biochemical diagnostic parameters of Red Sokoto goats fed tannin-rich Pterocarpus erinaceus forage diets. Vet Arhiv 81: 471-483.

10. Goering HK, Van Soest PJ (1970) Foragefiber analysis (apparatus, reagents, procedures and some application). USDA Agricultural Research Service.

11. AOAC (Association of analytical chemists) (1990) Official methods of analysis (15th edn.) Washington, DC

12. NRC, National Research Council (1981) National Research Council (NRC). In: Nutrient Requirements of Goats. Nutrient requirement of domestic animals, National Academy of Sciences, Washington DC, New York, pp: 10-12.

13. SAS, Statistical Analysis System (1999) User's guide. Statistics (SAS/SPSS version 10) SAS Inst Inco, Raleigh, New Cary, USA.

14. Ogungbesan AM, Akeem LA, Fajemisin AN, Mbomie SE (2011) Performance Characteristics of Tephrosia Bracteolata (Gull Et Perr) Based Diets on Cell Wall Fractions Digestibility and Nitrogen Retention In West African Dwarf Goats. J Environ Issues Agricult Develop Ctries 3: 2.

15. Tiwari SP, Jain RK, Mishra UK, Misra OP, Patel JR, et al. (2000) Effect of trace mineral (mineral capsules) supplementation on nutrient utilization and rumen fermentation pattern in Sahiwal cow (Bos indicus). J Animal Sci 70: 504-507.

16. Nagabhushana V, Sharma K, Pattanaik AK, Narayan D (2008) Effect of Cobalt Supplementation on Performance of growing Calves. Veterinary World. 1: 299-302.

17. Tiffany ME, Spears JW, Xi L, Horton J (2003) Influence of dietary cobalt source and concentration and performance, vitamin B12 
status, and ruminal and plasma mtabolites in growing and finishing steers. J Anim Sci 81: 3151-3159.

18. Smith R and Marston LH (1970) Production, absorption, distribution and excretion of vitamin B 12 in sheep. Br J Nutr 24: 857-877.

19. Jabbar MA, Cobbina J, Reynolds L (1992) Optimum fodder-mulch allocation of tree foliage under alley farming in southwest Nigeria. Agroforest Syst 20: 187.

20. Devendra C (1993) Trees and shrubs as sustainable feed resources. 7th World Conference on Animal Production, Edmonton, Alberta, Canada June 1: 119-136.
21. Simons AJ, Stewart JL (1994) 2.2 Gliricidia sepium-a Multipurpose Forage Tree Legume.

22. Huang T, Kim M, Wolff E, Nguyen A, Nguyen T, et al. (2003) Use of the rpoB gene to determine the specificity of base substitution mutations on the Escherichia coli chromosome. DNA Repair (Amst) 2: 593-608.

23. Ojai UI, Etima HE, Okoye FC (2007) Effects of urea and aqueous ammonia treatment on the composition and nutritive value of maize residues. Small Rumin Res 69: 232-236. 